Key words: prosociality, prosocial behavior, psychological mechanisms, emulation, object-oriented/ social perception, interiorization, identification, self-reflection, emotional switching, moral self-reflection, empathy, stereotypization, retrospection, goal setting and conceptualization.

УДК 159.922.7-053.6:[159.9.07:37.04]

М. О. КОЦЬ, Т. М. ЯТЧУК

DOI: https://doi.org/10.35619/prap rv.vi12.59

\title{
СПЕЦИФІКА ДІАГНОСТИКИ ОСОБИСТІСНОЇ СФЕРИ ПІДЛІТКІВ З ОСОБЛИВИМИ ОСВІТНІМИ ПОТРЕБАМИ
}

У статті проаналізовано особливості діагностики особистісної сфери підлітків, що мають особливі освітні потреби. Визначено основні напрямки корекиійної роботи. Доведено, що в учнів, які мають порушення в особистісній сфері, наявні проблеми у контролі власних дій та емоційних реакцій. Також присутні тривалі негативні переживання, пригнічений настрій та недостатня розвиненість вольових зусиль та наявні тривожні стани.

Визначені за результатами діагностики особливості особистісної сфери підлітків з особливими освітніми потребами створюють підтрунтя для розроблення програми корекиійних занять з метою розвитку вольових зусиль та зняття тривожних станів.

Ключові слова: особистісна сфера, підлітковий вік, особливі освітні потреби, діагностика, корекиійна робота.

В статье проанализированы особенности диагностики личностной сферы подростков, имеютих особые образовательные потребности. Определены основные направления коррекционной работы. Доказано, что у учащихся, которые имеют нарушения в личностной сфере, существующие проблемы в контроле собственных действий и эмоциональных реакций. Также присутствуют длительные негативные переживания, подавленное настроение и недостаточная развитость волевых усилий и имеющиеся тревожные состояния.

Определень по результатам диагностики особенности личностной сферы подростков с особыми образовательными потребностями создают основу для разработки программы коррекиионных занятий с целью развития волевых усилий и снятия тревожных состояний.

Ключевые слова: личностная сфера, подростковый возраст, особые образовательные потребности, диагностика, коррекиионная работа.

Постановка проблеми. В сучасних економічних та суспільно-політичних умовах дедалі більше зростає частка осіб, в яких діагностуються порушення особистісної сфери. Складні геополітичні умови значно впливають на емоційну сферу людини, стають причиною затяжних депресивних станів, домінування бурхливих негативних емоційних реакцій, розвитку тривожних та фобічних станів. Таким впливам піддаються не тільки дорослі, а й підлітки, які прагнуть вивчати різноманітну інформацію з засобів масової інформації щодо ситуації в своїй державі та світі, перебудовують відносини з оточенням та прагнуть отримати бажану самостійність. Низки невдач в цих прагненнях можуть спричинювати серйозні порушення особистісної сфери та викривлені сприйняття реальності. На сьогодні досить важливим $є$ вивчення детермінантів порушення особистісної сфери у підлітковому віці, з метою психопрофілактики та психокорекції можливих ускладнень.

Аналіз останніх досліджень і публікацій. Відомо, що підлітковий вік є одним із ключових періодів у життєвому циклі людини та пов'язується з відповідною системою завдань, можливостей, переваг, а також небезпек, криз, збитків. У науковій літературі він постає як третьою фундаментальною ерою у життєвому шляху особистості, для якої притаманні зміни у царині психе, сома і поліс. Підлітковий вік тісно пов'язується з трьома основними соціально-культурними світами: сім'єю, школою та групою однолітків [2]. Саме ці основні сфери взаємодії тісно пов'язані 3 подальшим розвитком особистісної сфери. Значну частку часу підлітки проводять в стінах навчального закладу, в якому розвиваються емоційна та вольова сфери підлітка під впливом референтних осіб, до яких відносимо однокласників, друзів та вчителів. Несприятливі умови виступають чинниками, які призводять до виникнення порушень в структурі емоційно-вольової сфери: невмінні контролювати власні емоційні реакції та дії, надмірній тривожності, затяжних негативних емоційних станах та переживаннях.

Вивчення психологічних засобів оптимізації поведінкових стратегій особистості постійно перебувало у полі зору дослідників $[1 ; 2 ; 3 ; 4 ; 5 ; 6$ та ін.]. Так, Є. Калюжна, досліджуючи у своєму дисертаційному дослідженні психологічні механізми особистісної тривожності у підлітковому віці, Випуск 12, 2019. Збірник наукових праць РДГУ 
виокремлює основні напрямки вивчення психологічних механізмів саморегуляції поведінки особистості: структурний конструкт особистості та іiі діяльності; сенсомоторна, емоційна, мотиваційна, вольова, моральна саморегуляція; механізми ціннісної саморегуляції [3]. Т. Кириченко, вивчаючи передумови розвитку саморегуляції поведінки підлітків, розглядає іiі як інтегративну якість особистості, яка охоплює мотиваційну, інтелектуальну, вольову, емоційну сфери. На думку автора дослідження, механізми саморегуляції реалізуються в індивідуальній формі, яка залежить від характеристик нервової діяльності, від особистісних якостей людини та ії звичок в організації своїх дій. Відтак, чим вищі показники регуляторного досвіду зовнішньої активності, тим вища ефективність саморегуляції поведінки [4, с. 53].

Таким чином, саморегуляція поведінки та емоційної сфери підлітків грунтується на психологічних механізмах, контролі поведінки, засвоєнні моральних процесів, усвідомленні етичних, моральних та суспільних норм, які потребують подальшого вивчення, зокрема, у тих дітей, які мають особливі освітні потреби.

Формулювання цілей статті. Мета дослідження полягає в емпіричному вивченні особистісної сфери підлітків з особливими освітніми потребами.

Виклад основного матеріалу дослідження. Вибірку становили учні спеціалізованого навчального закладу у кількості 23 осіб. До досліджуваної групи ввійшли учні 7-8 класів.

У дослідженні особистісної сфери основним методичним інструментарієм використано методику САН (самопочуття, активність, настрій), тест шкільної тривожності Філіпса та методику дослідження вольової саморегуляції А. Звєрькова та Є. Ейдмана. Тест САН спрямований на миттєву діагностику основних критерії самопочуття особистості - самопочуття, активність та настрій. Ми підрахували та визначили відсоток осіб які мають певні властиві їм рівні самопочуття на момент діагностування. У 91\% діагностованих спостерігається високий рівень оцінки самопочуття, що вказує на те, що досліджувані не відчували жодного фізичного та психологічного дискомфорту (рис.1). Проте 9\% учнів мали незадовільне самопочуття, тобто відчували певні больові синдроми або ж психологічний дискомфорт.

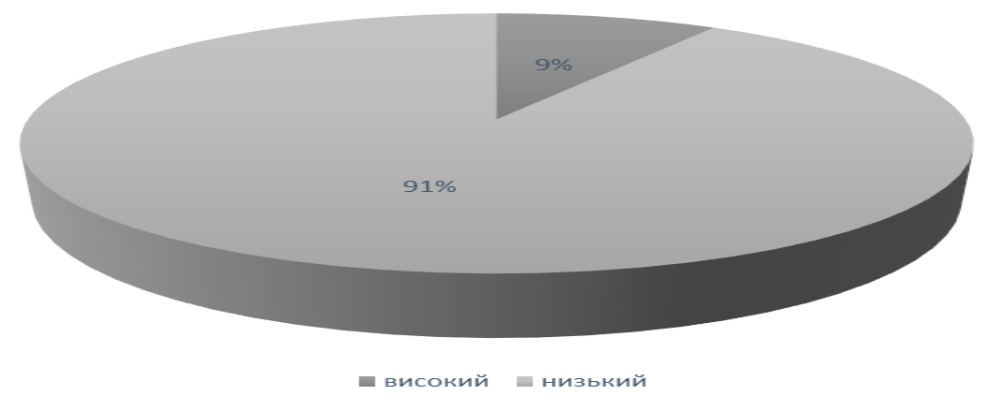

Pис. 1. Вираженість рівнів оцінки самопочуття особистості за методикою САН (самопочуття, активність, настрій)

Як показано на рис. 2, у 22\% учнів був високий рівень активності, тобто цим діагностованим було притаманне бажання активно взаємодіяти, включатися в роботу та виконувати поставлені дослідником завдання.

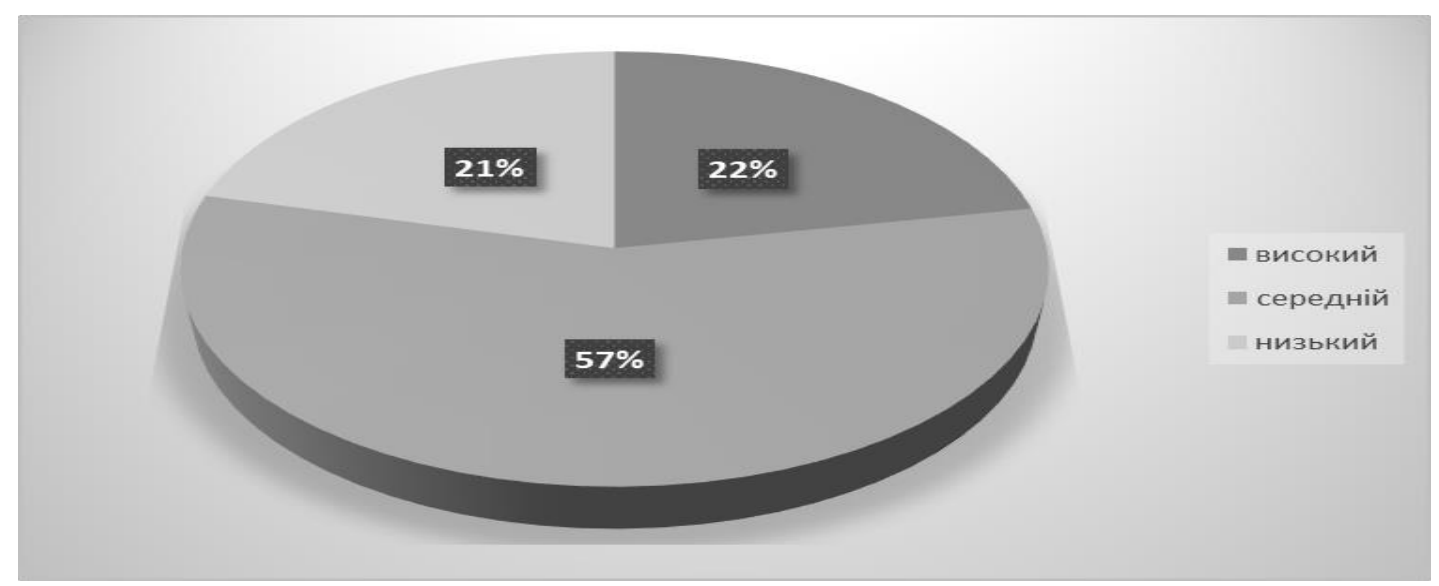

Puс. 2. Вираженість рівнів оцінки активності особистості за методикою САН 
57\% респондентів показали середній рівень, тобто під час взаємодії існували відволікаючі чинники. Наприклад, таким чинником може виступати фізична та психічна втома під час навчального процесу. Низький рівень активності властивий $21 \%$ учнів, що свідчить про небажання включатися в роботу, розсіяність уваги, труднощі у встановленні контактів з експериментатором, негативне емоційне та фізичне самопочуття.

За результатами, представленими на рис. 3, на момент діагностування високий рівень оцінки власного настрою був притаманний $57 \%$ учнів, що вказує на позитивну налаштованість, сприятливий емоційний стан та переживання позитивних емоцій. Середній рівень виявлено у $39 \%$ респондентів, що свідчить про дещо пригнічений настрій та наявність певних негативних емоційних переживань. $4 \%$ учням властиві низькі бали, що вказує на пригнічений настрій, негативні переживання та тривожність.

Тест шкільної тривожності Філіпса дозволяє визначити основні чинники, які спричинюють шкільну тривожність. До них відносять загальну тривожність в школі, переживання соціального стресу, фрустрованість потреби у досягненні успіху, страх самовираження, страх ситуації перевірки знань, страх невідповідності очікуванням оточення, низьку фізіологічну опірність стресам та проблеми і страхи в стосунках з педагогами.

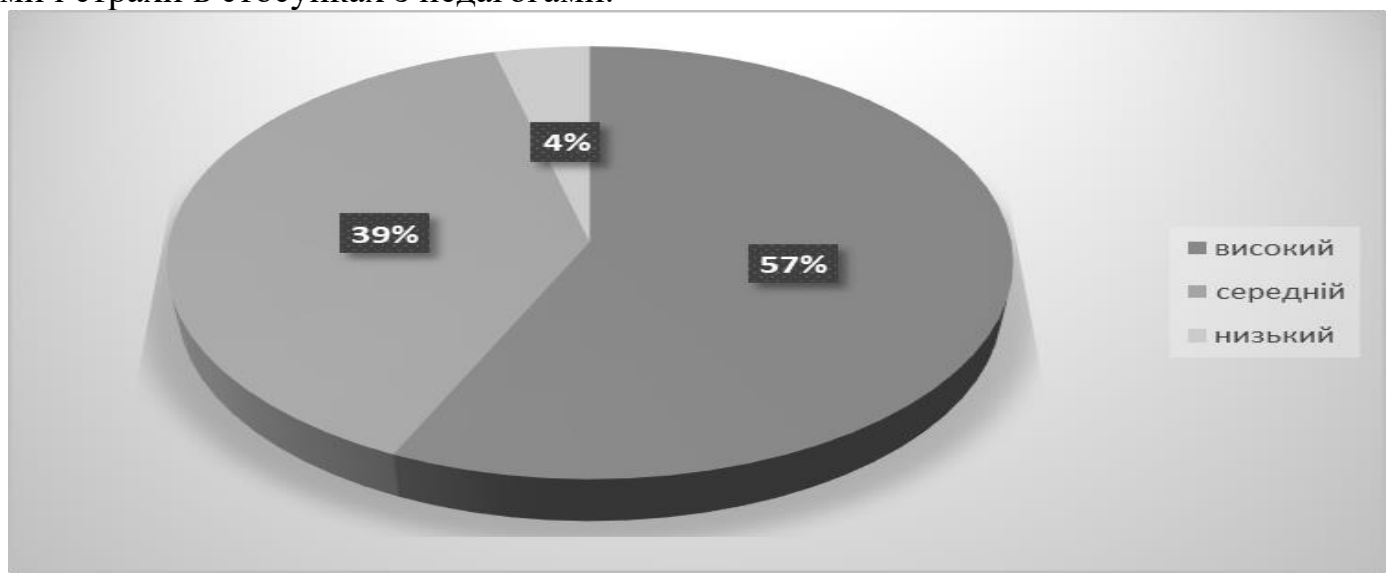

Puc. 3. Вираженість рівнів оцінки настрою особистості за методикою САН (самопочуття, активність, настрій)

Ми підрахували та визначили відсоток осіб у групі, що мають підвищений та високий рівень загальної тривожності в школі (рис. 4.).

Так, було встановлено, що у 13\% учнів існує підвищений рівень тривожності в умовах їх перебування в школі. Також, у 9\% діагностованих виявлено високий рівень тривожного емоційного стану, який пов’язаний із їх щоденною діяльністю в межах шкільного простору.

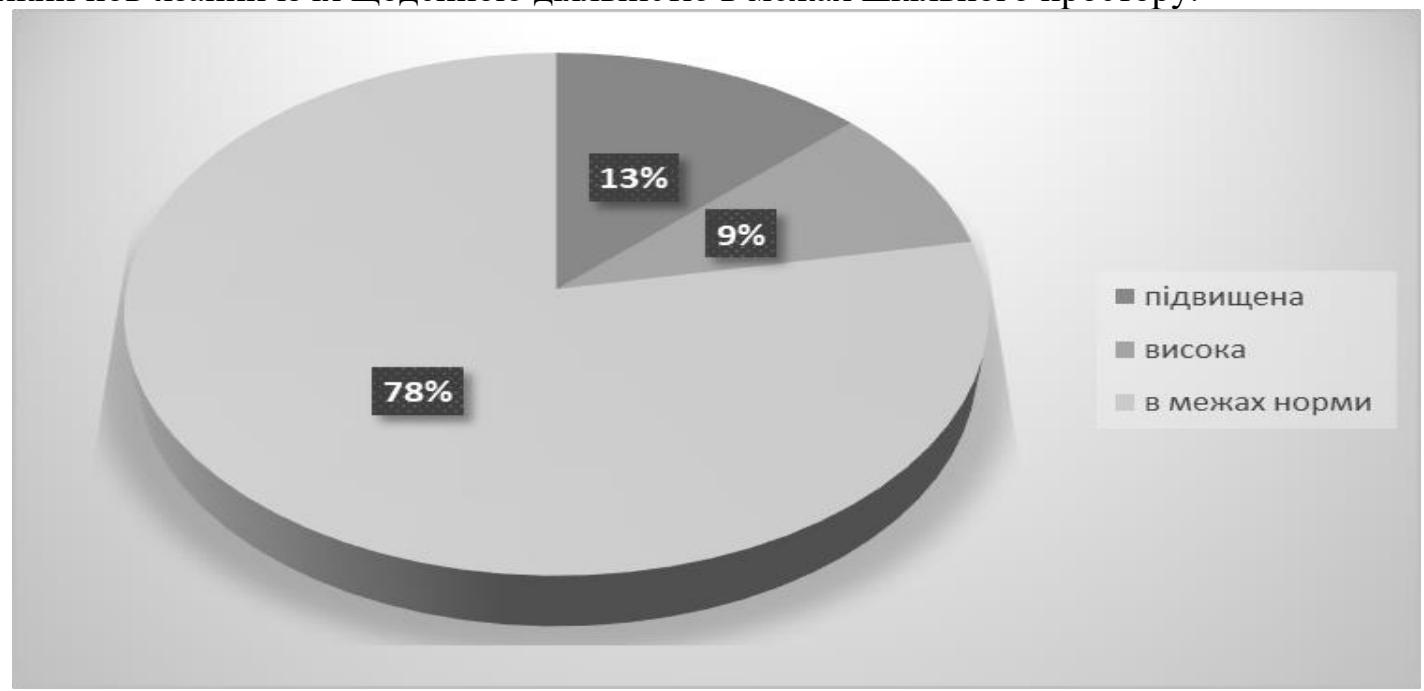

Рис. 4. Вираженість рівня загальної шкільної тривожності у діагностованої групи учнів

Згідно шкали «Переживання соціального стресу» (№2) в учнів 7-8 класів було виявлено 26\% дітей, які мають високий рівень тривожності, що детермінується складнощами у встановленні контактів, найчастіше з однолітками (рис. 5). У $30 \%$ учнів виявлено високий рівень тривожності за 
шкалою «Фрустрація потреби в досягненні успіху» (№3), який виявляється у несприятливому емоційному стані, що впливає на потребу в успіху та досягнення бажаних результатів (див. рис. 5).

За шкалою «Страх самовираження» (№4) підвищений рівень тривожності діагностовано у $17 \%$ респондентів та високий рівень - у 13\%, що вказує на негативні емоції, які виникають у ситуаціях самопрезентації та розкриття своїх можливостей (див. рис. 5).

Підищений та високий рівень тривожності за шкалою «Страх ситуації перевірки знань» (№5) було діагностовано $17 \%$ та 9\% учнів відповідно, який вказує на гостре переживання негативних емоційних реакцій та тривожних станів у момент аудиторної перевірки знань (див. рис. 5).

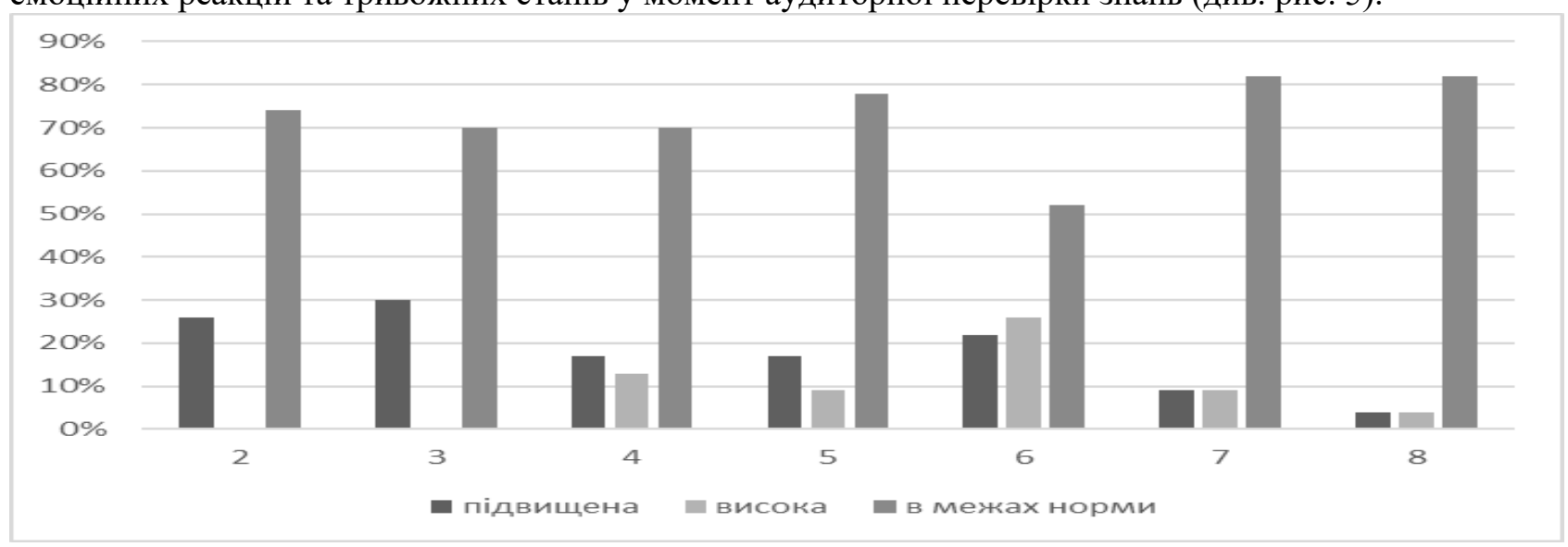

Рис. 5. Вираженість рівнів тривожності за шкалами методики Філіпса

Згідно шкали «Страх невідповідності очікуванням оточення» (№6) підвищений рівень тривожності було виявлено у $22 \%$ респондентів, тоді як високий рівень притаманний $26 \%$ учнів. Основною рисою поведінки таких дітей $є$ залежність від оцінки інших учнів, вчителів, батьків, надмірна тривога стосовно отриманих балів (див. рис.5.). За шкалою «Низька фізіологічна опірність стресу» (№7) високий та підвищений рівень тривожності притаманний по 9\% учнів, відповідно. Основним чинником виникнення тривожних станів $є$ психофізіологічні особливості організації учнів (див. рис. 5).

Згідно отриманих результатів за шкалою «Проблеми і страхи у стосунках з вчителями» у 4\% респондентів було виявлено високий рівень тривожності, також у $4 \%$ учнів було встановлено підвищений рівень, які вказують на напружені взаємостосунки з педагогами, які знижують загальну успішність в школі та можуть спричинювати гострі тривожні стани (див. рис. 5). Використання методики дослідження вольової саморегуляції А. Звєрькова та Є. Ейдмана спрямована на діагностику основних критеріїв вольової саморегуляції. Ми підрахували та визначили відсоток осіб які мають високий та низький результати згідно пунктів загальної шкали (рис. 6).

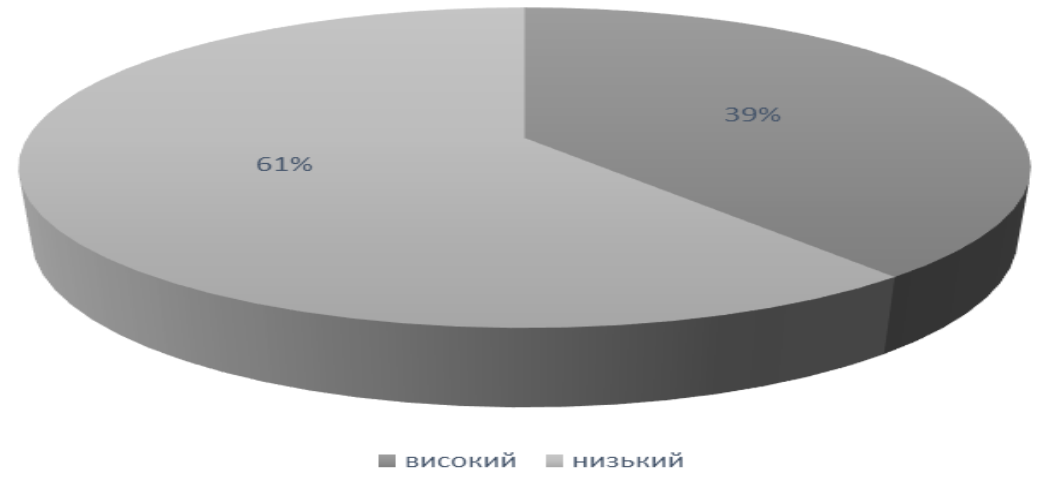

Pис. 6. Вираженість рівнів розвитку вольової саморегуляції учнів 7 - 8 класів за методикою А. Звєрькова та Є. Ейдмана

Високі результати властиві $61 \%$ респондентів, які свідчать про їх незалежність, зрілість та самостійність. $39 \%$ учнів мають низький бал, який вказує на емоційну нестійкість, невпевненість у собі та власних силах, надмірну чутливість до зовнішніх подразників, відсутність або недорозвиток рефлексивних навичок, надмірну імпульсивність, бурхливість прояву емоційних реакцій та нестійкість поглядів та переконань. 
Згідно даних, представлених на рисунку 7, 61\% учнів показали високий показник рівня розвитку наполегливості, який вказує на стійку силу намірів особистості, прагнення до успішного завершення розпочатих справ.

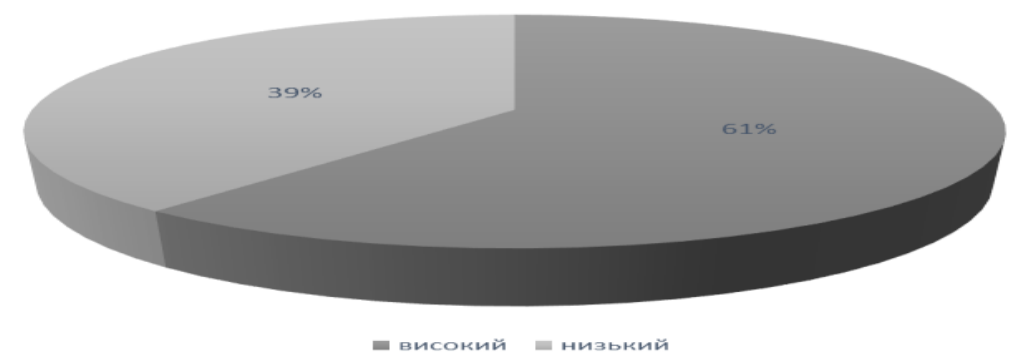

Рис. 7. Вираженість рівнів розвитку наполегливості в учнів 7 - 8 класів за методикою А. Звєрькова та Є. Ейдмана

Низький рівень притаманний 39\% опитаних учнів 7-8 класів. Він свідчить про надмірну імпульсивність, невпевненість в собі, непослідовність у думках та діях, певну хаотичність дій, вільним трактуванням соціальних вимог та норм, часто з власною вигодою.

Як показано на рисунку 8 , у $35 \%$ діагностованих наявний низький рівень розвитку навичок самоконтролю, що вказує на спонтанність поведінки та емоційних реакцій, надмірна уразливість, байдужий та різко негативний фон настрою.

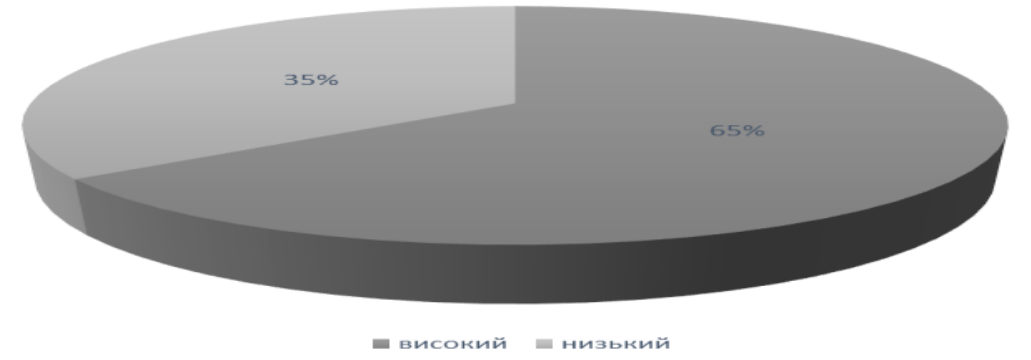

Pис. 8. Вираженість рівнів розвитку самоконтролю в учнів 7 - 8 класів за методикою А. Звєрькова та Є. Ейдмана

Високий рівень було виявлено у $65 \%$ учнів. Такі особи характеризуються розвинутим вмінням контролювати емоційні реакції, вчинки та дії, емоційною стійкістю, впевненістю у собі, внутрішнім спокоєм та стабільністю, прагненнями до новаторства та радикалізму.

Висновки 3 проведеного дослідження. Доведено, що в учнів, які мають порушення в особистісній сфері, наявні проблеми у контролі власних дій та емоційних реакцій. Також присутні тривалі негативні переживання, пригнічений настрій та недостатня розвиненість вольових зусиль та наявні тривожні стани. Визначені за результатами діагностики особливості особистісної сфери підлітків з особливими освітніми потребами створюють підгрунтя для розроблення програми корекційних занять $з$ метою розвитку вольових зусиль та зняття тривожних станів.

\section{Список використаних джерел}

1. Вереніч Н. Особливості тривожності сучасних підлітків / Н. Вереніч // Психолог. - 2004. № 23-24. - С. 41-42.

2. Дуркалевич I. Емоційні риси підлітків, які зростають у заробітчанських сім'ях [Електронний ресурс] / І. Дуркалевич // Педагогіка і психологія професійної освіти. - 2014. - № 1. C. 125-134. - Режим доступу : http://nbuv.gov.ua/UJRN/Pippo_2014_1_14

3. Калюжна Є. М. Психологічні механізми особистісної тривожності у підлітковому віці : автореф. дис. ... канд. психол. наук : 19.00.07 / С. М. Калюжна ; НПУ ім. М. П. Драгоманова. - Київ, 2008. $-24 \mathrm{c}$.

4. Кириченко Т. Передумови розвитку саморегуляції поведінки підлітків [Електронний pecypc] / Т. Кириченко // Гуманітарний вісник Державного вищого навчального закладу "ПереяславХмельницький державний педагогічний університет імені Григорія Сковороди". Психологія. - 2016. Вип. 38. - С. 79-87. - Режим доступу : http://nbuv.gov.ua/UJRN/gvphpups_2016_38_11 
5. Коць М. О. Особливості психологічної корекції емоційно-вольової сфери дітей молодшого шкільного віку з особливими освітніми потребами / М. О. Коць, Т. М. Ятчук // Психологія: реальність і перспективи : зб. наук. пр. Рівнен. держ. гуманіт. ун-ту / упоряд. : Р. В. Павелків, Н. В. Корчакова ; ред. кол. : Р. В. Павелків, В. І. Безлюдна, Н. В. Корчакова. - Рівне : РДГУ, 2018. - Вип. 10. - С. 85-92.

6. Коць М. О. Психолого-педагогічна корекція та фізична терапія дітей 3 особливими освітніми потребами: програма дослідно-експериментальної роботи / М. О. Коць, А. М. Тучак // Медико-біологічні проблеми фізичного виховання різних груп населення, ерготерапії, інклюзивної та спеціальної освіти : матеріали ІІІ наук.-практ. конф., (м. Луцьк, 31 січ. 2018 р.) / ред. В. В. Чижик. Луцьк : ПВД «Твердиня», 2018. - С. 49-50.

\section{References}

1. Verenich N. Osobly`vosti try`vozhnosti suchasny`x pidlitkiv / N. Verenich // Psy`xolog. - 2004. - № 23-24. - S. 41-42.

2. Durkalevy`ch I. Emocijni ry`sy` pidlitkiv, yaki zrostayut` u zarobitchans`ky`x sim'yax [Elektronnyy resurs] / I. Durkalevy`ch // Pedagogika i psy`xologiya profesijnoyi osvity`. - 2014. - № 1. S. 125-134. - Rezhy`m dostupu : http://nbuv.gov.ua/UJRN/Pippo_2014_1_14

3. Kalyuzhna Ye. M. Psy`xologichni mexanizmy`osoby`stisnoyi try`vozhnosti u pidlitkovomu vici : avtoref. dy`s. ... kand. psy’xol. nauk : 19.00.07 / Ye. M. Kalyuzhna ; NPU im. M. P. Dragomanova. Ky`yiv, 2008. - 24 s.

4. Ky`ry`chenko T. Peredumovy` rozvy`tku samoregulyaciyi povedinky` pidlitkiv [Elektronnyy resurs] / T. Ky`ry`chenko // Gumanitarny`j visny`k Derzhavnogo vy`shhogo navchal`nogo zakladu "Pereyaslav-Xmel`ny`cz`ky`j derzhavny`j pedagogichny`j universy`tet imeni Gry`goriya Skovorody`. Psy`xologiya. - 2016. - Vy`p. 38. - S. 79-87. - Rezhy`m dostupu: http://nbuv.gov.ua/UJRN/gvphpups_2016_38_11

5. Kocz` M. O. Osobly`vosti psy`xologichnoyi korekciyi emocijno-vol`ovoyi sfery` ditej molodshogo shkil`nogo viku z osobly`vy`my` osvitnimy` potrebamy` / M. O. Kocz`, T. M. Yatchuk // Psy`xologiya: real`nist` i perspekty`vy` : zb. nauk. pr. Rivnen. derzh. gumanit. un-tu / uporyad.: R. V. Pavelkiv, N. V. Korchakova; red. kol. : R. V. Pavelkiv, V. I. Bezlyudna, N. V. Korchakova. - Rivne : RDGU, 2018. - Vy`p. 10. - S. 85-92.

6. Kocz`M. O. Psy`xologo-pedagogichna korekciya ta fizy`chna terapiya ditej z osobly`vy`my` osvitnimy` potrebamy`: programa doslidno-ekspery`mental`noyi roboty` / M. O. Kocz`, A. M. Tuchak // Medy`ko-biologichni problemy` fizy`chnogo vy`xovannya rizny`x grup naselennya, ergoterapiyi, inklyuzy`vnoyi ta special’noyi osvity`: materialy` III nauk.-prakt. konf., (m. Lucz`k, 31 sich. 2018 r.) / red. V. V. Chy`zhy`k. - Lucz`k : PVD «Tverdy`nya», 2018. - S. 49-50.

\section{O. Kots, T. M. Yatchuk THE SPECIFICITY OF DIAGNOSTICS OF PERSONAL SPHERE OF YOUNG PEOPLE WITH SPECIAL EDUCATIONAL NEEDS}

The diagnostics features of the personal sphere to adolescents with special educational needs analyzes in this article. The main directions of correctional work are defined.

It is proved that self-regulation of behavior and emotional sphere of teenagers is based on psychological mechanisms, control of behavior, assimilation of moral processes, awareness of ethical, moral and social norms. The main problem is the lack of knowledge of self-regulation of adolescents and its impact on the emotional and personal sphere.

The sample was made by students of specialized educational institution (educational and rehabilitation center) in the number of 23 people. Pupils in grades 7-8 consisted the investigated group.

The main methodological tools used are the SAM inquirer (state of health-activity-mood), the Filipsa school anxiety test and the method of study volitional self-regulation A. Zvierkova and Ye. Eidmana in the study of the personal sphere.

It is proved that students with violations in the personal sphere, there are problems in the control of their own actions and emotional reactions. There are also long-term negative experiences, depressed mood and lack of development of volitional efforts and anxiety.

According to the results of certain diagnostic features of personal sphere of young people with special educational needs provide the basis for the development of a programme of remedial classes for the purpose of development effort and relieve anxiety.

Key words: personal sphere, adolescence, special educational needs, diagnostics, correctional work. 